\title{
THE AMERICAN CONGRESS AND CZECHOSLOVAK MONETARY GOLD, 1980-1981
}

\author{
SLAVOMÍR M I C H Á L E K
}

MICHÁLEK, Slavomír. The American Congress and Czechoslovak Monetary Gold, 1980-1981. Historický časopis, 2019, 67, 5, pp. 879-904. Bratislava.

The history of the Czechoslovak monetary gold began to be written at the end of the 1930s at the time of the mutilation and break up of the Czechoslovak Republic. The gold was forcibly and illegally seized by Nazi Germany. At the end of the Second World War, the American army of occupation found it in salt mines at Merkers in Germany with gold from other countries. It was only in 1982 that an adequate part was returned to the vaults of the State Bank of Czechoslovakia in Prague.

Soon after the Second World War, the USA, Great Britain and France established the Tripartite Commission for the Restitution of Monetary Gold on the basis of decisions by the Paris Reparations Conference. Its task was to secure the just and proportional return of recovered gold to all the affected countries including Czechoslovakia. During the following decades of the Cold War, gold was a regular subject of conflict, dispute and negotiations, especially between Washington and Prague. The agreements reached were cancelled by one side or the other, and they repeatedly went back to the beginning. This study is directed towards the period 1980-1981, when the United States Congress significantly intervened in the question of the return of the Czechoslovak gold.

Key words: Tripartite Commission for the Restitution of Monetary Gold. Lester Wolff. Compensation for nationalized property. Czechoslovak monetary gold, the US Congress and Czechoslovakia, 1980-1981.

DOI: https://doi.org/10.31577/histcaso.2019.67.5.5

The eventful history of the Czechoslovak gold began to be written at the end of the 1930s, at the time of the mutilation and break-up of the Czechoslovak Republic. It was illegally and forcibly seized by Nazi Germany, as also happened in other European countries. At the end of the Second World War, the American army of occupation found it in salt mines at Merkers near Frankfurt upon Main, and for almost four decades it was involved in international economic, commercial, political and ideological disputes. It was only in 1982 that an adequate part 
was returned to Prague or to the vaults of the State Bank of Czechoslovakia. ${ }^{1}$ In the present study, I have directed my attention to years 1980 and 1981.

The Czechoslovak monetary gold already appeared continually in exchanges of diplomatic communication between the USA and Czechoslovakia from soon after the Second World War, although Prague's communication with the Tripartite Commission for the Restitution of Monetary Gold was supposed to be what mattered. The commission of representatives of the USA, Great Britain and France was established in 1946 on the basis of a decision by the Paris Reparations Conference. Its purpose was to secure the proportionate and just division and return of the recovered gold to all the affected countries including Czechoslovakia. In the following decades of the Cold War, the gold appeared regularly as an object of conflict, disputes and negotiations, mainly involving Washington and Prague. Agreements were reached but broken by one side or the other and they often started again from the beginning. Precisely in the years 1980 and 1981 the US Congress significantly intervened in the question of returning the gold. It is necessary to note that this was to the disadvantage of Czechoslovakia.

Although the history of the Czechoslovak monetary gold is not a major theme in modern Czechoslovak or international history, it is definitely not trivial. Up to now, Slovak and Czech historiography has not devoted full attention to the subject, but it has not been avoided. Several studies have traced the development of the questions surrounding the Czechoslovak gold at least marginally or have concentrated only on the year 1939. However, a scientific monograph by a historian, capturing the whole history of the gold on the basis of the accessible sources, still does not exist. ${ }^{2}$

1 This study is a result of the project APVV-16-047 Od denára k euru, fenomén peñazí $v$ dejinách Slovenska od stredoveku po súčasnost' (From the denár to the euro, the phenomenon of money in the history of Slovakia from the Middle Ages to the present), researched at the Institute of History of the Slovak Academy of Sciences.

2 The book by Stanislav Motl Kam zmizol zlatý poklad republiky. (Where did the golden treasure of the republic disappear to) (Prague 2003) is not based on archive research and does not take into account all the accessible archive sources. It is more a publicist, sensationalized work, based on memoir literature and oral testimony. The historians, who have mapped parts of the problem using the primary sources, include especially the Czech authors Jan Kuklík: Do posledni pence... (To the last penny...) whose monograph on Czechoslovak - British relations includes financial and commercial questions, Vít Smetana: Británie a československé zlato. (Britain and the Czechoslovak gold.). In Soudobé dějiny 4/2001), also Eduard Kubů: Czechoslovak Gold Reserves and their Surrender to Nazi Germany. In Nazi Gold (London 1998) and Jan Krejčí: Několik poznámek k historii navrácení československého měnového zlata. (Some notes on the history of the return of the Czechoslovak monetary gold.). In Právnik, 7/1996. The three last named are scientific studies, which concentrate especially on the question of the degree of responsibility of the British government for handing over part of Czechoslovakia's gold to Germany in 1939. The accessible literature mapping the questions around the Czechoslovak monetary gold or the wider connections of Czechoslovak - Ameri- 
Talks about the open economic and financial questions between Czechoslovakia and the USA including those about the gold, passed through phases of stagnation and revival from the beginning. ${ }^{3}$ There was a hopeful revival of development in the property law issues between Czechoslovakia and the USA in 1980. First of all, on 13 May 1980, member of the House of Representatives Lester Wolff proposed act no. 7338, according to which the Czechoslovak gold held in the USA had to be taken and sold to satisfy the claims on nationalized American property in Czechoslovakia. Senator Daniel Moynihan submitted a similar proposal on 15 May 1980.

The other proposers of New York Congressman Wolff's proposed legislation "to satisfy the claims of American citizens and the USA against Czechoslovakia from the value of gold belonging to the Czechoslovak state and to settle the remaining assets of Czechoslovakia" were the US Congressmen Joseph Fisher, Barber Conable, Richard Ottinger and Thomas Downey. The proposal required that after the act came into force, the Secretary of State would start negotiations with Czechoslovakia on the full and immediate settlement of all claims recognized by the Foreign Claims Settlement Commission established in 1949. ${ }^{4}$ If the Secretary of State did not submit a preliminarily signed agreement on the settlement of American claims within 60 days from the acceptance of the act by the

can, at least according to their titles, should include the work by Justine Faure: Americký pritel. (American friend). Unfortunately, it is not so. It is a work that captures Czechoslovak political developments after 1945 as seen through the eyes of a Western author. In contrast, the Czechoslovak gold receives attention in the memoirs of Bohuslav Chňoupek Memoáre in claris, former Czechoslovak Minister of Foreign Affairs. It is necessary to mention here that he was more oriented towards his personal participation, impressions and feelings, although the facts he provides show that he had access to the ministry's documents. In terms of content, the most useful work devoted to the Czechoslovak - American relations, including the problem of the gold comes from the pen of Zdeňek Trhlík, a former Czechoslovak diplmat. This book, published in 1988 under the title Spojené státy a Československo. Vztahy v letech 1918-1988 (The United States and Czechoslovakia. Relations: 1918-1988) as a result of research at the Institute of International Relations, using contemporary terminology and evaluations, is the most valuable publication concerned with this problem in terms of presentation of the facts.

3 For more details on the talks about the gold starting from 1945 see: MICHÁLEK, Slavomír. The Tripartite Commission and the Czechoslovak Monetary Gold. In Historický časopis (Historical Journal), 2017, vol. 65, no. 5, p. 895-930. ISSN 0018-2575.

4 This American Commission completed its work on 15 September 1962, when it signed the final decision on 3976 claims. It rejected 1346 of them and accepted 2630. The total value of the recognized claims amounted to 113645205 USD, so after deduction of the sum of 8.5 million USD obtained from sale of the steel rolling mill, the final size of the American claims was about 105.1 million USD. In Archiv Ministerstva zahraničních věcí ČR (Archives of the Ministry of Foreign Affairs of the Czech Republic), (hereinafter AMZV ČR), f. MPO, Rokovania o československom zlate zv. II, diel A. (Talks on the Czechoslovak gold, vol. II, part A). Record of the talks on 24 March 1981, p. 2. 
US Congress, or if Congress did not approve the agreement within 60 days of its submission, the Secretary of State had to implement the following measures:

1. Take possession and control over the Czechoslovak monetary gold and other gold found in the territory of the USA, and sell this gold to achieve the greatest possible profit;

2. To request the consent of Great Britain and France to the sale of the Czechoslovak monetary gold located in the territory of Great Britain;

3. To deposit the profits from sale of the gold in securities, bonds or bank accounts. The interest, dividends and other income from these resources would be distributed to the recognized creditors at six monthly intervals;

4. After payment of all recognized claims to compensation, to pay Czechoslovakia the money from sale of the gold after deducting a charge for administrative costs not exceeding $5 \%{ }^{5}$

In his speech to Congress on 13 May 1980, Congressman Wolff estimated that settlement of all the American claims to interest and other income from invested and deposited sums gained by sale of the Czechoslovak gold would take about five years if Great Britain and France agreed to the sale of gold deposited outside the USA. If only the gold deposited in the USA was available, the payment of claims would take about 11-21 years. In the report justifying his proposal, Wolff pointed to the fact that 30 years before Czechoslovakia had nationalized American property in its territory and still paid no compensation for this property. $\mathrm{He}$ also pointed out that the claimants were older people, for whom obtaining compensation for their property was an urgent social question. At the same time, he stated that the fact that the question of nationalization had not been solved was an obstacle to normal diplomatic, commercial and economic relations.

Wolff's proposed legislation was not concerned with the international legal aspects of the proposed approach, especially in relation to the agreement on reparations from 14 January 1946. It was limited only to the statement that the new legislation would supplement and clarify that agreement.

The conception of Wolff's proposal started from the statement that the USA controlled the Czechoslovak monetary gold either directly in the case of the part located in the territory of the USA or indirectly in the case of the gold outside US territory. However, from the point of view of international law, this was not true. The return of monetary gold was subject to the Agreement on reparations required from Germany, the establishment of the Inter-Allied Reparations Office and the restitution of monetary gold from 14 January 1946, which had been

5 AMZV ČR, f. MPO, Rokovania o ..., vol. II, part A. Record of the proposed legislation of the USA on the sale of Czechoslovak gold. 
signed by almost 20 states. The third part of this agreement spoke of the restitution of the monetary gold.

The problem of return of the gold was explicitly separated in the agreement from the problem of reparations. States had a claim to restitution of monetary gold, if they had lost gold during the war as a result of German theft or illegal transfers. In contrast to this, reparations were supposed to compensate for war damage and expenses to the states which had been in a state of war with Germany. This agreement entrusted the governments of the USA, Great Britain and France with distributing the gold they had found between the damaged states, but they had no right to dispose of this gold. On the contrary, the agreement explicitly required them to do everything necessary to achieve its distribution on the basis of detailed and verifiable documents and information. Therefore, Wolff's proposed legislation on the sale of Czechoslovak gold was a coarse and discriminatory violation of obligations the USA had accepted in January 1946. This agreement and general international law did not allow unilateral "supplements" or "clarification". If the USA was going to sell the Czechoslovak gold, it had to achieve a change in the agreement from January 1946 and the agreement of Great Britain and France was not enough for that. The agreement could be changed only with the consent of all its signatories.

In spite of this, the issue of Wolff's proposal to Congress developed to the disadvantage of Czechoslovakia. The representatives of the Czechoslovak Ministry of Foreign Affairs protested to the American Embassy in Prague against Wolff and Moynhan's proposals, describing them as unacceptable pressure on Czechoslovakia. Soon after, on 26 May 1980 Ambassador Mechan submitted an official proposal from the government of the USA on the solution of the open economic and financial questions. On the basis of the high market value of gold at the time, the US administration demanded full compensation for nationalized American property amounting to 72.6 million USD with the addition of interest amounting to 41 million USD, which meant payment of almost $160 \%$ of claims. The total was 113.6 million USD from which they would deduct 8.5 million USD, which the USA had gained from sale of a steel rolling mill. ${ }^{6}$ Thus, Czechoslovakia had to immediately pay 105.1 million USD all at once (the settlement of other communist countries with the USA in the question of compensation represented $40 \%$ of the claims). ${ }^{7}$

6 For more details on the talks about the Czechoslovak rolling mill see: MICHÁLEK, Slavomír. Spor Československa a USA o širokopásovú valcovňu v rokoch 1951 - 1954. The dispute between Czechoslovakia and the USA about a steel rolling mill, 1951-1954). In Historický časopis, 2006, year 54, no. 4, p. 607-630. ISSN 0018-2575.

7 AMZV ČR, f. MPO, Rokovania o ...., vol. II, part A, A new American proposal to solve the open economic and financial questions between Czechoslovakia and the USA, Supplement B. 
This new proposal by Washington essentially started from the preliminarily signed agreement from 1974, but with one substantial difference. It was the size of the total compensation. ${ }^{8}$ How does comparison of the two texts look?

Articles 1-3 of the 1974 agreement stated that to achieve complete settlement, the Czechoslovak side had to pay the government of the USA 20.5 million USD, with 4 million USD on the day the agreement became valid, and the rest in annual instalments of 1.37 million USD over 12 years.

The new proposal from 26 May 1980 spoke of a different sum. Czechoslovakia would have to pay capital of 72.6 million USD and interest of 41 million USD, making a total of 113.6 million USD, from which 8.5 million USD had to be deducted for the rolling mill. Thus, the total demand of the American side climbed to 105.1 million USD. Moreover, in this proposal, payment was demanded in full on the day the agreement became valid. Instalments over years were not proposed.

If we compare the texts from 1974 and 1980, we see that the conditions for Czechoslovakia had substantially worsened in two ways:

a) the total amount demanded had increased from 20.5 mil. to 105.1 mil., a sum of almost 85 million USD;

b) instead of payment in instalments over 12 years, the new proposal demanded payment on the day the agreement became valid.

The other points in the American proposal from 1980 did not contain any radical changes. There were only some different verbal combinations and expressions of the content of the above mentioned agreement from 1974. For example, art. 7 of the agreement stated that after signing of the agreement, the government of the USA would inform the tripartite commission that it agreed to the release of 18.4 tonnes of gold to the Czechoslovak government, while point 2 of the new American proposal spoke of the day of agreement, when the agreement would become valid, and they were two different dates. However, these questions had only a formulative character and did not represent basic deviations from the 1974 agreement.

Apart from these major questions of the property law settlement between Czechoslovakia and the USA, there were other demands, which both sides had tried to solve in the previous documents from 1964 and 1974. The American

8 The agreement from 1974 collapsed because of the size of the total compensation. Washington, taking into account especially the demands of American citizens for compensation for nationalized property in Czechoslovakia, considered the negotiated amount to be inadequate and disadvantageous for the American side. The political aspects of the bipolar world were also significant, and the unwillingness by one side or the other to find a compromise flowed from this. 
demands towards Czechoslovakia included the debt from the so-called surplus agreement (a base of 4.9 million USD with interest of 3.2 million USD up to 31 December 1979), blocked crown accounts (the so-called Plzen account of the American army in the Živnostenská bank amounting to 7161557 Kčs and the so-called film account of the American embassy in Prague with 887691 Kčs) with a total value of about 1.5 million USD, as well as the unsettled dollar bonds from pre-war loans (these were the Czechoslovak state loan from 1922 and 1924, the mortgage loan of the city of Prague from 1922, and the foreign loan to the town of Karlovy Vary in 1924) amounting to 4 million USD. These cases amounted to a sum of 13.6 million USD.

The Czechoslovak claims against the USA were lower. According to the federal Ministry of Finance, the sum varied around 2.5 million USD, and included blocked, vested and other receivables, unpaid so-called prisoner of war certificates of Czechoslovak prisoners from the Second World War, some machines and equipment blocked in the USA. ${ }^{9}$

We obtain another interesting fact connected with the inflationary development of the dollar by comparing the agreement from July 1974 with the American proposal from May 1980. In the period 1974-1980 compensation for global inflation grew from 20.5 million USD to 27 million USD. According to financial experts at the State Bank of Czechoslovakia (SBCS), this had to be taken into account in further discussions. However, this was not the most interesting thing for Czechoslovakia. The main thing was another indicator: the development of the price of gold or the change in the sum gained from sale of the 18.4 tonnes Czechoslovak monetary gold. On 20 June 1974 during the final talks on the agreement, the price of a troy ounce of gold was 165 USD, on 30 August 1980 it was 670 USD and on 25 September 1980 already 707 USD, although in later years it declined.

It is easy to calculate from these figures that the 18.4 tonnes of Czechoslovak gold (only from weight, without the agio of coins) was worth 97.6 million USD in June 1974, 372.7 million USD in August 1980 and 428.3 million USD in September $1980 .{ }^{10}$ These literally amazing figures were an important new reality for Czechoslovakia. Without any "help" from the USA or Czechoslovakia, the rocketing growth of the price of gold entirely overturned the situation. Instead of a deficit with the USA, Czechoslovakia had a large surplus.

The American proposal from the end of May 1980 was resolutely rejected by the Czechoslovak side "as coarse and entirely unjustified discrimination against

9 AMZV ČR, f. MPO, Rokovania o ..., vol. II, part A, New American proposal to solve the open economic and financial questions between Czechoslovakia and the USA, Supplement D.

10 AMZV ČR, f. MPO, Rokovania o ..., vol. II, part A, New American proposal to solve the open economic and financial questions between Czechoslovakia and the USA, Supplement E. 
Czechoslovakia”. ${ }^{11}$ On 18 July 1980, the American ambassador in Prague presented America's reaction to the Czechoslovak position to the Foreign Ministry. It was another phase in the semi-official exchange of views, and was formulated in a much more moderate tone. The ambassador indicated that compensation on the level of $60 \%$ could be a realistic basis for discussions, which the State Department could take to Congress, and there was no mention of interest payments. ${ }^{12}$

Acceptance of the $60 \%$ level of claims would mean payment of 43.5 million USD by the Czechoslovak side. Czechoslovakia could realistically count on the calculated 8.5 million USD for the rolling mill, with 35 million USD remaining after its deduction. In these circumstances, the Federal Ministry of Foreign Affairs considered it appropriate to react to the new American proposal. The "spectre" of the acceptance of Wolff's bill still existed.

In an attempt to gain support for acceptance of Wolff's bill no. 7338 by Congress, expecting the settlement of the claims of American citizens from the sale of Czechoslovak monetary gold, two legal experts, advocate Leslie Logan and former member of the legal department of the State Department Harry McPherson submitted their position to the Sub-Committee of the US Senate for Europe and the Middle East, the Sub-Committee for International Economic Policy and Trade and the Foreign Relations Committee of the House of Representatives on 19 August 1980. In their view, Great Britain and France no longer had any justified interest of any sort in the 9 tonnes of Czechoslovak gold controlled by the United States and physically held in the Federal Reserve Bank in New York under the legal jurisdiction of the USA. Allegedly, the Tripartite Commission had the duty only to divide the gold. Once this was done the commission and its members allegedly had no further direct or indirect legal power over the gold.

The two treaty documents, namely the Paris Agreement on Reparations and the Statute of the Tripartite Commission, regulated responsibility for division of the gold differently. The division of the gold had to be done collectively and unanimously. However, the job of doing the division was entrusted to individual members of the governments of the Tripartite Commission without the demand for unanimity. Harry Truman had also allegedly not asked the Tripartite Commission for approval, when he decided to block the return of the Czechoslovak gold. Neither Great Britain not France had participated in the bilateral Czecho-

11 AMZV ČR, f. MPO, Rokovania o ..., vol. II, part A, Proposed procedure for the settlement of property rights between Czechoslovakia and the USA, p. 3.

12 The position of the American ambassador from 18 July 1980 was confirmed on 24 July 1980 by the representative of the Deputy Secretary of State R.L. Barry in a discussion with the Czechoslovak ambassador in Washington Johanes. He also proposed talks about compensation for nationalization on the level of $60 \%$. AMZV ČR, f. MPO, Rokovania o ..., vol. II, part A, p. 4. 
slovak - American talks in 1974, and so their approval was not necessary. If Great Britain and France had some vague technical obligation according to the Paris Reparations Agreement from 1946 or the Tripartite Commission from the same year, then it was only to assist in the distribution of the gold assigned to Czechoslovakia. However, with regard to the fact that Czechoslovakia had violated international law by confiscating American property in Czechoslovakia without compensation, the US Congress was allegedly entitled to change, supplement or cancel an international treaty, so that it could satisfy the claims from Czechoslovak property that was located in the USA and was under American legal jurisdiction.

According to Logan and McPherson, the decisions of the Tripartite Commission did not have to be unanimous. Such agreement allegedly concerned only the original determination of the share of the gold and not any later considerations by members of the Tripartite Commission in the course of implementation of the treaty. Allegedly, the USA did not need the agreement of Great Britain and France to the sale of the Czechoslovak gold. The adoption of supplement no. 408 to the Commerce Act stating that the USA would not release the Czechoslovak gold controlled directly by the United States according to the Paris Reparations Agreement from 24 January 1946, allegedly established the right of the USA to negotiate independently about the gold without consulting Great Britain and France. With regard to the fact that Czechoslovakia had not paid for the nationalized property, the USA had the right in international law to adopt counter-measures. ${ }^{13}$ The Czechoslovak side rejected this American argumentation. The International Law Committee at the Ministry of Foreign Affairs in Prague considered that a substantial aspect of the American position supporting Wolff's bill was that the constitutional authorities of the USA did not regard the compensation agreed by the American government as adequate.

The support of the US Congress for Wolff's bill regarding the sale of Czechoslovak gold significantly strengthened the negotiating position of the State Department in relation to Czechoslovakia. The increased demand for compensation was justified by the State Department with the argument that if the Czechoslovak side rejected the American offer, there was a risk the bill on sale of the gold would be accepted and a higher level of compensation would have to be paid. A situation was created in which the Czechoslovak side could either accept the American demands, or, if not, it would bear responsibility for the further development.

13 AMZV ČR, f. MPO, Rokovania o ..., vol. II, part A, Speech by Leslie Logan and Harry McPherson to the Foreign Relations Committee of the House of Representatives from 19 August 1980. 
The Czechoslovak side tried to neutralize the American position by casting doubt on the realism and prospects of the efforts directed towards selling the Czechoslovak gold. The Prague Ministry of Foreign Affairs recalled the fact that the Smathers and Merrigan law firm, which stood behind the whole affair, had already tried in 1975-76 to obtain a judicial decision on the legality of selling the Czechoslovak gold and using the resources to satisfy the demands of American claimants. This demand was rejected as inadmissible from the legal point of view by the court of the District of Columbia and the Federal Appeal Court. They had not appealed within 30 days to the Supreme Court of the USA.

The Czechoslovak side proposed to use the legal situation in the USA, where the courts had the right to declare acts passed by Congress invalid if they contradicted the Constitution of the USA or international treaties, to defend itself during the talks, in propaganda or in court cases after the acceptance of the act. ${ }^{14}$ According to the Czechoslovak position, the USA could trivialize the Czechoslovak position because acceptance of Wolff's proposal could be in conflict with American legislation. In the field of propaganda, the Czechoslovak Federal Ministry of Foreign Affairs helped by its representative office in Washing-ton proposed to address important American publicists, who would point to the American rejection of the agreement from 1974, or that the Czechoslovak side was prepared to attack the law by the judicial route in the American courts, even in the Supreme Court. The ministry also proposed to discuss all the nuances and finesses of American law with the appropriate specialists in Moscow. They would also contact the former senator and important advocate William Fulbright and ask for his view. If Fulbright confirmed the correctness of the Czechoslovak approach, this judicial trump card could be used in the next discussions with the State Department. At the same time, the Czechoslovak Foreign Ministry recommended that its representative office in Washington should renew its contacts with Wolff, who was willing to "cooperate" with the Czechoslovak government by getting Congress to adopt his proposal not in the form of an act, but only as a non-binding resolution. ${ }^{15}$

On 22 January 1981, the embassy in Washington supported the argumentation on initiating a judicial dispute, but it called for caution because it did not expect that the president would veto the legislation or that an American court would rule in favour of a socialist country in a dispute between the USA and Czechoslovakia. It also proposed a sober assessment of the situation in Congress because no congressman supported the Czechoslovak position. Without regard

14 AMZV ČR, f. MPO, Rokovania o ..., vol. II, part A, Proposed counter-measures against the present pressure from the USA in its negotiations with Czechoslovakia on property rights. 9 January 1981.

15 AMZV ČR, f. MPO, Rokovania o ..., vol. II, part A, ibid. 
for the Czechoslovak argumentation on the justice and legality of the Czechoslovak case, which was entirely justified from the point of view of international law, the members of Congress saw the issue entirely as a question of defending the interests of American citizens. The embassy in Washington proposed using personal contacts to explain the Czechoslovak position and argumentation to senators and to promote a further confirmation of the negative view of the sale of the gold from Great Britain and France as members of the Tripartite Commission. They would actively use this position in talks with the members of Congress. They should also carefully watch the approach of the new Reagan administration and modify Czechoslovak policy accordingly. ${ }^{16}$

What were the stronger and what were the weaker aspects of the Czechoslovak position? Among the stronger aspects, we can place mainly the international dimension of the Tripartite Commission and the USA's associated obligations from 1946, as well as the propaganda that the USA was robbing its ally from the Second World War. A weaker aspect was the fact that the USA as the Western super-power did not intend to make concessions to demands from a satellite in the Eastern Bloc, which would complicate the fulfilment of plans in favour of its own citizens. This was clearly improbable.

For a comprehensive understanding of the positions of the USA and Czechoslovakia on the question of the gold, it is necessary to return to the beginning of autumn 1980. The Czechoslovak side expressed its preference for a return to the comprehensive agreement on property rights from 1974. At the same time, it raised as a negotiating element in its favour, the fact that the United States had refused to treat Czechoslovakia according to the most favoured nation principle by relaxing export controls on some types of technology. ${ }^{17}$ The Czechoslovak side considered that the agreement from 1974 was acceptable for both sides, but it conceded to the American proposal to raise the overall level of compensation to $60 \%$, meaning 43.5 million USD in relation to the total sum of 72.6 million USD. After deduction of the acknowledged 8.5 million USD for the steel rolling mill, the above-mentioned 35 million USD remained to be paid. Apart from this direct raising of the cost, the Czechoslovak side proposed a substantial shortening of the deadline for payment. In comparison with Wolff's proposal for payment over 9 years and the calculation of 21 years from the US Treasury/ Ministry of Finance, entitled creditors would have to wait four and a half years according to the Czechoslovak proposal. Moreover, at an interest rate of 4-6\%,

16 AMZV ČR, f. MPO, Rokovania o ..., vol. II, part A, position of the representative office in Washington from 22 January 1981.

17 Czechoslovak exports to the USA reached 59 million USD in 1979, but losses as a result of discriminatory customs duties associated with lack of most favoured nation status cost 11 million USD, so that direct loss for the Czechoslovak side represented 6 million USD. 
they would gain a further 35 million USD from their capital over 16 years, which far exceeded the level of $60 \%$. After 9 years it meant $64.7 \%$ and $79.2 \%$, that is 47.01 million USD and 57.5 million USD. After 21 years it would be $104 \%$ and $158 \%$, that is 75.5 million USD and 114.6 million USD. ${ }^{18}$ These figures in percentages and dollars calculated by employees of the Ministry of Foreign Affairs in Prague, had their value as evidence. They clearly showed what argumentation the Czechoslovak side could use in the expected discussions between experts from the two countries, when defending the level of $60 \%$ of the American claims to compensation. The question was: what position would prevail in the discussions: political or expert?

The Czechoslovak side brought further statistical data into the on-going game of chess between Czechoslovakia and the USA, in an effort to defend the trend of its position. The International Law Department of the Ministry of Foreign Affairs provided information for the ministry proposing that if the USA rejected the $60 \%$ settlement of claims, Czechoslovak negotiating position would have to return to the 1974 agreement and refuse to renegotiate it. However, this would lead to the danger that Congressman Wolff's bill would be adopted, and that at least the part of the Czechoslovak monetary gold held by the USA would be sold. The sale would also happen at a low price. However, if agreement could be reached with the USA, the whole 18.4 tonnes of gold would be returned to Czechoslovakia. Therefore, the International Law Department of the ministry offered the minister data about the market value of the Czechoslovak gold, and its value with calculation of the 50-100\% agio for gold coins.

The market value of the 18.4 tonnes of Czechoslovak monetary gold using the price in mid October 1980, namely 680 USD for one troy ounce, was 402.3 million USD. Gold ingots weighing $8003 \mathrm{~kg}$ (175 million USD) and $206 \mathrm{~kg}$ of coins (4.5 million USD), making a total of $8209 \mathrm{~kg}$ (179.5 million USD) were deposited in the USA. Only Czechoslovak gold coins weighing $10191 \mathrm{~kg}$ (222.8 million USD) were deposited in Great Britain. When calculating the agio for gold coins at an average level of 50-100 \%, the market value of the Czechoslovak gold in the USA was calculated as 6.75 million USD at $50 \%$ agio or 9 million USD at $100 \%$ agio. The gold in Great Britain was worth 334.2 million USD at $50 \%$ agio, or 445.6 million USD at $100 \%$ agio. Taking into account the agio, the total value of the gold in the USA and Great Britain was 334.2 million USD at $50 \%$ agio for the coins and 629.6 million USD at $100 \%$ agio. The American demand connected with nationalization plus the return of interest made 113.6 million USD or 105.1 million USD after deduction of 8.5 million USD for the rolling mill. Considering the market value of the Czechoslovak gold including

18 AMZV ČR, f. MPO, Rokovania o ..., vol. II, part A, explanation of the Czechoslovak proposal for settlement of property rights with the USA, supplement G. 
agio, Czechoslovak would gain 18.4 tonnes of gold worth 410.85 million USD at $50 \%$ agio or 524.5 million USD at $100 \%$ agio even after paying the whole of the American claim to money from nationalization and interest.

In connection with the solution of these basic problems, namely compensation for nationalization and release of the Czechoslovak gold, it was also necessary to solve other mutual debts, including the so-called surplus credit, loans from the period before the Second World War, blocked crown accounts in the USA, blocked Czechoslovak assets in the USA, which represented 13.5 million USD, so that the total Czechoslovak obligations towards the USA represented 118.7 million USD. The Czechoslovak obligations towards Great Britain including inter-governmental loans and the remaining demands from nationalization, represented 61.4 million USD. The total of Czechoslovakia's obligations to Britain and America amounted to 189.1 million USD. With the agio on coins calculated at 50-100 \%, Czechoslovakia would gain 336 million USD at 50\% agio or 449.7 million USD at $100 \%$ agio after the payment of American and British demands from nationalization or other financial claims. ${ }^{19}$

Apart from the American threat to sell the Czechoslovak gold, these dollar values for the obligations and gains for Czechoslovakia deriving from the market values and agios of the Czechoslovak monetary gold were the factor that motivated the Czechoslovak side to seek the best possible steps in relation to the USA. They also proved that not solving the question of the gold or freezing the Czechoslovak - American dialogue would represent the worst variant.

After various exploratory discussions, the American side announced on 16 December 1980 that it was willing to send a group of experts to Prague for discussions on the property-rights problem. In the course of March to August 1981, five rounds of discussions took place alternately in Prague and Washington between the delegations led by ambassadors Jaroslav Žantovský and Roseanne Ridgway. The Czechoslovak side was motivated by the effort to achieve the return of the monetary gold and fear that it would be sold by the Americans. It saw the gold as a substantial gain. The American side gave priority to the demand for compensation for nationalized property. These were the two points of dispute that had lain before the two states for more than three decades. The other open economic and financial questions were less serious, but the key to their solution lay in the gold and in compensation.

The first block in the five rounds of discussions between Czechoslovak and US experts was concerned with finding a consensus on the open economic and financial questions, and happened in Prague on 23-26 March 1981. The Czechoslovak side presented its position on the first day and the partners from the USA

19 AMZV ČR, f. MPO, Rokovania o ..., vol. II, part A, Information for the minister of foreign affairs on the problem of settlement of property rights between Czechoslovakia and the USA. 
on the second. Since the American side had an eminent interest in solving especially the question of compensation for nationalized property, it informed the Czechoslovaks mainly about the procedure for discussions and recognition of the compensation claims of the USA. ${ }^{20}$ The head of the American delegation, Ambassador R. Ridgway did not avoid the question of the size of the American claims, namely 113645205 USD, or 105.1 million USD after deduction of 8.5 million USD for the rolling mill, according to her calculation.

The Czechoslovak side operated with a sum of 72.6 million USD and the chief of its delegation, Ambassador Jaroslav Žantovský explained that in all the previous talks, the USA had claimed this sum. However, Ridgway explained that the difference in the American position was a result of the development of events since 1974, and the American side was not offering a discount because demands for 200 or more million USD were appearing and many had still not been investigated.

Prague wanted to keep the sum down to 72.6 million USD as offered by Ambassador Meehan in 1980, and considered it problematic that the USA had a tendency to add interest to the claims. Allegedly these were not caused by the Czechoslovak side, because it wanted to agree with the USA, and so it had signed the 1974 agreement. The Czechoslovak delegation included in the total of 72.6 million USD domestic and business property, securities and shares. It also refused to link this question with the question of the Czechoslovak gold. The American delegation did not want to retreat from its sum, so Ridgway repeated that the sum of 105.1 million USD was correct and just. It was composed of 72.6 million USD plus 41 million USD interest. She also explained that the American experts had brought to the Prague talks in 1980 especially the well-known bill proposed to Congress to sell the Czechoslovak gold. In this way, she indicated that Congress was interested in the steps of the State Department, which was expected to achieve an agreement acceptable to Congress. She did not see her mission in Prague in terms of research into claims, interest and so on, but as a matter of passing on the conviction of the government of the USA that the sum they proposed had a chance to be approved by Congress. Essentially, she openly stated that the American side would accept a one-off payment of 105.1 million USD, or that this would be approved by the US Congress. On the other hand, Žantovský described the American demand as an element that blocked possible

20 Every American demand was registered and assigned to a lawyer, who had to decide whether the claim fulfilled the requirements in terms of American citizenship of the claimant, ownership of the property or a share of it, value, date and circumstances of loss. After these facts were proved, the demand was assessed by a commissioner, who issued a preliminary decision after an analysis. If the claimant disagreed with the decision, he could appeal and submit new evidence. Then a final decision would be taken. 
dialogue and agreement. Using undiplomatic language, he stated that only advocates would gain from such idle talk. Ridgway replied that her role was to find out the Czechoslovak position, and she would not discuss proposals she already knew would not be accepted. ${ }^{21}$ So what was the result of these discussions? Essentially, zero, since the positions did not come any closer. The fact that the Czechoslovak side learnt very clearly that in the talks between two institutions - the Czechoslovak Foreign Ministry and the US State Department - the decision of a third - the US Congress would be decisive, can be described as a positive result.

In an effort to clarify the position in the discussions on property rights, the chiefs of the delegations made an agreement that they would try to find a starting point in an informal meeting between the two of them. This discussion also involved maintenance of positions with neither side willing to get out of its trench. The Czechoslovak side insisted on the sum of 72.6 million USD and the US side on 105.1 million USD (72.6 mill. plus interest of 41 mill. USD minus 8.5 million USD for the rolling mill). However, Žantovský and Ridgway agreed that the on-going official talks at least confirmed a clear political interest of both sides in seeking a solution. After it was achieved, the USA would release the Czechoslovak tri-partite gold. There was also a small shift by the Czechoslovak side, which saw the firm position of the USA and abandoned the sum of 72.6 million USD, namely $60 \%$ of the compensation without interest payments. It offered to pay a total of 20.5 million USD in compensation. The first instalment after the physical delivery of the gold in natura would be 4 million USD, with the rest paid in 12 equal instalments, which meant according to the 1974 agreement. The American ambassador reacted to this position by abandoning the sum of 105.1 million USD and proposing a sum of 90 million USD. ${ }^{22}$ The third day of talks in the first round did not bring any movement. The position of the two sides remained unchanged. Ridgway summarized the first round as useful, because it identified the dimensions of the problem in the context of the domestic situation in the two countries. The Czechoslovak side refused to discuss a sum of more than 72.6 million USD. The sum of 105.1 million USD was entirely unacceptable for Czechoslovakia. However, the two sides were willing to look for an acceptable solution in further talks.

After returning to Washington, Ridgway informed the administration and the members of Congress about the course of the talks. On 19 May 1981 she returned to Prague with two American proposals:

21 AMZV ČR, f. MPO, Rokovania o ..., vol. II, part A, record of the second day of discussions on 24 March 1981.

22 AMZV ČR, f. MPO, Rokovania o ..., vol. II, part A, Record by Jaroslav Žantovský of the private talks with the head of the American delegation Ambassador Roseanne Ridgway on 24 March 1981. 
1. Czechoslovakia should pay 105 USD, 65 million immediately and 40 million in the course of three years;

2. Czechoslovakia should pay 95 million USD immediately.

Ridgway presented these proposals as an American concession, and said that it would be better to pay 95 million USD immediately, because the first proposal with payments over three years also delayed the question of release of the Czechoslovak gold. Žantovský refused to negotiate under pressure, that is under the threat that the gold would be sold by the US Congress. He reacted with a summary of the talks so far, with lower compensation sums, which Ridgway described as a superfluous historical and rhetorical exercise, as she defended the American position. She strongly rejected the new Czechoslovak proposal to pay $65 \%$ of the basic 72.6 million USD, namely 47.19 million USD. Czechoslovakia demanded the same $65 \%$ for the rolling mill, meaning that it was willing to pay 36.79 million USD. Ridgway proposed to suspend the talks but continue an unofficial search for points of agreement. At the same time, she declared that the administration saw the lowest chance of gaining the approval of Congress in an immediate payment of 82 million USD. ${ }^{23}$ Although the American side unofficially again admitted a lower sum for compensation, the opposing views did not come close. Neither side really wanted to make concessions, although Czechoslovakia was in the worse position because the threat of the sale of the Czechoslovak monetary gold still hung in the air.

The third round of talks, on 29 June 1981, in Prague happened relatively quickly. Ridgway informed that she had discussed the new Czechoslovak proposal with the State Department and Congress. This proposal - a Czechoslovak payment of 64.1 million USD with addition of 16 million USD (Czechoslovak payment for the rolling mill) and 8.5 million USD (Argentine payment to the USA for the rolling mill) - had been considered by the American side and rejected because compensation for inflation was also needed. Ridgway stated that the sum of 64.1 million USD had no hope of being approved by Congress. As a conciliatory gesture, she presented a reduced American demand of 90 million USD. Since the official talks were clearly leading nowhere, the Czechoslovak side proposed informal discussions. In a discussion between Ridgway and Žantovský, the American ambassador repeated the sum of 82 million USD from the second round. Žantovský essentially accepted the American sum. Czechoslovakia agreed to satisfy the American claim to about 80 million USD, but with the condition that this would be accompanied by the return of most favoured nation status from which Czechoslovakia had been illegally excluded by the United

23 AMZV ČR, f. MPO, Rokovania o ..., vol. II, part A, property rights negotiations - second round of talks. 
States 30 years before in the framework of the General Agreement on Tariffs and Trade (GATT).

However, Ridgway refused to retreat on anything connected with the greatest advantage, and she added that most favoured nation status would probably have priority for solution after the signing of an agreement. ${ }^{24}$

The fourth round of compensation talks between Czechoslovakia and the USA was held on 16-17 July 1981 in Washington. The Czechoslovak delegation submitted a new proposal of 81.5 million USD, but this total compensation would be paid in instalments. The first payment of 15 million USD would be paid to the USA at the same time as the handing over of the 18.4 tonnes of gold. Further payments would make up 15\% of the annual exports from Czechoslovakia to the USA, with the USA receiving $50 \%$ of the annual increase of the quantity of Czechoslovak exports to the USA..$^{25}$ Žantovský also stated that the settlement for the nationalization of American property was not actually 81.5 million USD but an amount higher by 16 million USD, namely the Czechoslovak payment for the rolling mill, and 8.5 million USD, which Argentina had paid to the USA for the rolling mill. Ridgway again rejected the Czechoslovak offer. It was no longer a matter of the size of the compensation, but of the method of payment. She insisted that Czechoslovakia should pay the sum of 81.5 million USD all at once. The Czechoslovak side finally gave up the game of nerves or the marathon of talks. On the next day, 17 July 1981, Žantovský informed Ridgway that the Czechoslovak side was willing to pay the sum of 81.5 million USD all at once and at the same time as the handing over of the 18.5 tonnes of gold. He described this as the final Czechoslovak proposal. ${ }^{26}$

The positions reached by the two sides in Washington in mid-July 1981 came close enough together for Ridgway and Žantovský to present their work as a success. The fifth round of talks could be left to technical experts. The question remains: Who gained more or lost more, the USA or Czechoslovakia? Czechoslovakia gained an agreement that would lead to the handing over of 18.4 tonnes of Czechoslovak monetary gold. Its holding by the USA had been an expression of great power politics and harsh discrimination by the USA with the aim of obtaining compensation. However, the market value of the gold in 1945 was diametrically different. Its price was many times higher in 1981. What did the USA gain? Compensation for nationalized property substantially higher than at

24 AMZV ČR, f. MPO, Rokovania o ..., vol. II, part A, record of the Czechoslovak - American talks in Prague on 29 June 1981.

25 For illustration, in 1980 Czechoslovakia's exports to the USA were worth 81 million USD. According to the Czechoslovak proposal, the USA would receive 12 million USD.

26 AMZV ČR, f. MPO, Rokovania o ..., vol. II, part A, record of the property rights talks with the USA in Washington on 16 and 17 July 1981. 
the beginning of the talks, and the return of the gold was not tied to the return of most favoured nation status.

The final round of the expert discussions on the text of the agreement on settlement of the open economic and financial questions between Czechoslovakia and the USA was held on 12-14 August 1981 in Prague. They no longer discussed the size of the compensation, but started from the view that the role of the delegation was to improve the text of the initialled agreement from 1974 on the basis of the consensus from 17 July 1981. This especially hindered the Czechoslovak position, since the 1974 agreement was more advantageous to the Americans. The changes or amendments to the 1974 text relate to the following provisions:

1. Article 1 contained a new definition of the range of American properties for which compensation would be paid. The original formulation did not make it clear whether properties placed under national administration were included. This evoked the theoretical danger that in the future, the American side could also demand compensation for them. On the initiative of the American delegation, they again discussed the question of guarantees against possible further claims to compensation connected with nationalization and other procedures that caused harm to the other side. In this way, the American delegation tried to ensure that in the future Czechoslovakia could not claim compensation for losses that Czechoslovakia suffered in connection with the sale of the rolling mill. The provision that excluded this possibility was originally part of the text of the 1964 agreement, but it was not found in the 1974 text. Therefore, the Czechoslovak side firmly insisted on a text that guaranteed to both sides that there would be no further claims. Moreover, they negotiated the tying of this provision to the demand for a supplement to article 10, which had a form that did adequately prevent the application of Czechoslovak claims to the release of blocked property in the USA.

2. Article 2 was newly formulated. The previous version had not assured that there would be no future new claims against Czechoslovakia to compensation by American citizens, who had claims to nationalized firms or firms otherwise taken over by the Czechoslovak state. The new formulation excluded this.

3. Article 4 was supplemented with a provision that the USA would send Czechoslovakia copies of decisions about compensation together with their justification. The previous text had secured only the sending of the names of the persons who had been harmed, but this did not enable the Czechoslovak authorities to find out the real state of American property in Czechoslovakia. 
4. Changes to articles 8 and 9 were preliminarily agreed. Article 8 from 1974 included a provision that the American representative office in Prague would be able to use 7 million Kčs in its account at the Živnostenská banka only after agreement with the Ministry of Foreign Affairs. The American side demanded a change to this provision, because its existing form gave the Czechoslovak side the possibility to block these resources and allegedly Congress would not allow this. The Czechoslovak delegation was willing to change the text so that these resources could be used in Czechoslovakia for the needs of the American representative office in harmony with the Czechoslovak legal order under the condition that the American side would agree to a change in the text of article 9. The change to the text of this article concerned the provision according to which the Czechoslovak side would deposit a sum of 1.5 million USD in the American account at the Živnostenská banka, and the USA would be able to draw Czechoslovak crowns either according to the rate at the time of the deposit or according to the rate at the time of withdrawal, whichever was most advantageous for them. This unusual provision could cause significant problems in the future, because the problem of what resources the State Bank of Czechoslovakia would use to pay for the different in exchange rate would have to be solved.

5. Article 10 concerned the release of blocked Czechoslovak property in the USA. Czechoslovakia had evidence of claims amounting to 0.4 million USD. However, according to unofficial information, property amounting to 1.4 million USD was blocked in the USA. Therefore the Czechoslovak delegation insisted that the provision of article 10 be supplemented with an obligation of the American side to assist with Czechoslovak efforts to regain blocked properties, especially by providing Czechoslovakia with lists. In the end, the American side agreed, especially when the Czechoslovak delegation made the new version of article 10 a condition for accepting the new version of article 1 .

6. In supplements A and B to the agreement, which regulate the method of handing over the monetary gold and the Czechoslovak cheques to compensate for American property, the State Bank of Czechoslovakia and the Ministry of Finance proposed Switzerland as the only possible route for the hand over process. The USA would never agree to receive the cheques only when the gold was already in Czechoslovak territory or the reverse. However, the 1974 agreement stated that a Czechoslovak letter signed by the minister of finance of Czechoslovakia to the Swiss bank that was mediating the transfers, would be sent with the mediation of the US government and would be irrevocable without the written consent 
of the USA. According to the new text, Czechoslovakia would send the letter directly to the Swiss bank and it would be possible to revoke it only after agreement between Czechoslovakia and the USA. The 1974 agreement also precisely determined the procedure for handing over the Czechoslovak gold. It defined the deposit right of the bank, and stated that if the cheques were not handed over, the gold would be returned to the Tripartite Commission. However, there was no similar provision about the Czechoslovak cheques. The Czechoslovak side was only bound to hand over the cheques to the Swiss bank, without provision for their return if the planned transfer did not happen. This could lead in practice to Czechoslovakia having no legal claim to the return of cheques for a sum of almost 85 million USD in the event that the USA stopped the hand over of the gold at the last minute. Therefore, the new text was supplemented to exclude this danger.

7. The American delegation proposed that the gold to be transferred to Switzerland would be kept in the account of the Tripartite Commission in the names of the governments of the USA, Great Britain and France until it was handed over. This would fully secure its immunity against legal action in the Swiss courts. Since this would legally worsen the position of the Czechoslovak gold, the Czechoslovak delegation set this question aside for detailed consideration.

8. A whole series of amendments and clarifications of a technical nature were added to the text of the agreement and its supplements after the mutual agreement. ${ }^{27}$

However, acceptance of the text of the compensation agreement did not end the roundabout of talks about the return of the gold. The subject returned, although only briefly, to the Tripartite Commission and to Congress. A series of discussions of the return of the Czechoslovak gold was held in Paris on 1-4 December 1981. The talks were bilateral and in the framework of the Tripartite Commission. The American delegation was led by R. Ridgway, the British by A. Montgomery and the French by J. Dalbert, who was also the chairman. The commission itself was represented by its general secretary C. Harris.

The Czechoslovak delegation was made up of Richard Kral and M. Kotora from the International Law Department of the Ministry of Foreign Affairs, Jan Krejčí from the Federal Ministry of Finance and Jiří Nálevka from the State

27 AMZV ČR, f. MPO, Rokovania o ..., vol. II, part A. Information about the expert talks between Czechoslovakia and the USA on the text of the agreement on the solution of financial and property rights questions between the two countries from 17 August 1981. 
Bank of Czechoslovakia - all experts, who accompanied Jaroslav Žantovský at talks with the USA. At first, the Americans talked to the French in Paris, then both had discussions with the British in the framework of the Tripartite Commission. These talks concentrated on the French and British demand that Czechoslovakia should accept full responsibility for all the risks associated with transfer of the gold to Switzerland. Czechoslovak - British and Czechoslovak - American bilateral talks followed. The British delegation refused to accept responsibility for the risks associated with handing over the gold in Switzerland, and insisted that Czechoslovakia should accept these risks. They insisted that Czechoslovakia should explicitly give up claims against Great Britain and the Tripartite Commission if something unforeseen happened in connection with the gold. The Czechoslovak delegation categorically refused.

The whole of these British-Czechoslovak talks in Paris took place in a strained atmosphere thanks to the nervousness of the British representatives, who were irritated by any mention of the Czechoslovak - American compensation deal. After emotive Czechoslovak argumentation about the moral, political and legal responsibility of Great Britain for the theft of the Czechoslovak gold, the British delegation accepted a compromise formulation, which did not insist on the text about Czechoslovakia taking full responsibility.

The talks between the Czechoslovak delegation and R. Ridgway's delegation were held at the American embassy soon after the talks with Great Britain. Ridgway informed the Czechoslovaks about her talks with the French, who had clearly expressed the view that they did not want to be an obstacle to the handing over of the Czechoslovak gold. She also presented the progress of approval of the compensation agreement in the USA, where it had been submitted to Congress on 30 November 1981. Apart from this, a special team from the State Department headed by Eagleburger, deputy to Secretary of State Haig, was talking to influential figures in Congress including the most interested senators and congressmen about how to ensure it would be discussed quickly. They did not expect problems in the Senate, where the agreement had to be approved without debate, but sharp opposition to the agreement might appear in the House of Representatives.

Further talks between the Czechoslovak delegation and Great Britain were held on 4 December 1981 at the Czechoslovak representative office in Paris. They discussed the provision of the Czechoslovak - British compensation agreement including supplements. The majority of the provisions were relatively quickly agreed. Great Britain only wanted to place the question of responsibility for the transfer of the gold entirely on the shoulders of Czechoslovakia. ${ }^{28}$

28 AMZV ČR, f. MPO, Rokovania o ..., vol. II, part A, record of the talks in Paris on 8 December 
For example, the prepared agreement did not solve the question of the harm caused to Czechoslovakia by the Munich Agreement and handing over of 23 tonnes of gold to Nazi Germany. Other questions did not appear to be controversial. Both sides made compromises or conciliatory steps. The British delegation informally promised that an agreement could be signed during a visit by the British deputy foreign minister to Prague on 14-16 December 1981.

The Paris talks between Czechoslovakia and the Tripartite Commission did not omit the technical questions regarding the transfer of the Czechoslovak gold, where four problematic areas stood out:

1. A mechanism for claiming compensation for differences in the weight of the assigned gold, which could arise if the received gold ingots and coins did not have the prescribed fineness. The Tripartite Commission was striving to reduce the importance of this problem by pointing out that about 300 tonnes of gold had already been distributed, and no claims had appeared, or that the Tripartite Commission could not guarantee the fineness of coins and gold ingots, because it had only what was entrusted to its administration. In the end, however, after confirmation from a representative of the Bank of England on the correctness of the Czechoslovak legal view, that the very term "monetary gold" used in the text of the 1946 agreement showed that there must be concern for the fineness of the gold, so the commission recognized that the Czechoslovak demand was justified. It proposed that before coins were handed over to the Czechoslovak side, they should be investigated, and if it was found that they did not contain the prescribed amount of gold, this would be corrected. The Czechoslovak delegation rejected this, because there were about a million coins and an investigation would take 3-4 months, which would delay the return of the gold to Czechoslovakia. No solution to this question between the commission and Czechoslovakia was found. The fineness of the gold ingots was equally problematic. The commission was not able to answer the question of whether these ingots had internationally recognized marks of fineness or the appropriate recognized certificates.

2. The Czechoslovak delegation pointed out that the British note from 13 June 1958 informed them that their share would be $18433.4735 \mathrm{~kg}$ of gold, but then the weight was 18.4 tonnes. The commission explained that the difference of $33.4735 \mathrm{~kg}$ arose because the quantity of gold to be returned was rounded down to the nearest $50 \mathrm{~kg}$. The commission also stated that the 18.4 tonnes was only a preliminary and Czechoslovakia

1981, p. 3 etc. 
would get about 33.5 more in the final reckoning when the problem of the Albanian gold had been solved.

3. Where insurance of the gold until its handing over to the Czechoslovak side was concerned, the Tripartite Commission stated that it would ask the Swiss who would carry out the transaction, to prepare a concrete proposal. The Czechoslovak side rejected this - since it was Czechoslovak gold, it wanted to pay for the insurance itself. This proposal was motivated by the consideration that if a Czechoslovak insurance company participated in insuring the gold, it would significantly reduce the cost to Czechoslovakia.

4. The Czechoslovak side demanded and eventually succeeded in securing its basic requirement that the formulation expressing the Czechoslovak claims and content of the other basic documents must be the same as for other states. $^{29}$

The talks in Paris practically solved the remaining problems in relation to Great Britain and created the conditions for solution of the main questions connected with transfer of the monetary gold in relation to the Tripartite Commission. This completed an important stage. What steps did the Czechoslovak side still have to pursue?

- The Federal Ministry of Foreign Affairs (FMFA) had to submit to the Central Committee of the Communist Party of Czechoslovakia and government comprehensive information about the gold and about solution of the open economic questions with the USA and Great Britain with a proposal to sign the negotiated compensation agreements;

- The FMFA proposed initialling of the Czechoslovak - British agreement during the coming visit of the British deputy foreign minister to Prague;

- The FMFA proposed to the Tripartite Commission that the coins would be investigated in Prague by Czechoslovak experts with the participation of two expert observers from the commission. If they find coins that evoke doubts about their gold content, they would be secured and submitted to the Tripartite Commission for expert investigation;

- The State Bank of Czechoslovakia, FMFA and Federal Ministry of Finance would work out and submit to the Tripartite Commission proposals for insurance of the gold during its transport from New York and London to Switzerland and its deposit in a Swiss bank until it was transferred to the account of the Czechoslovak government;

29 AMZV ČR, f. MPO, Rokovania o ..., vol. II, part A, ibid, p. 6-7. 
- The FMFA would negotiate with the Swiss Bank Corporation the mechanism for the transaction; ${ }^{30}$

- The expected problematic approving of the compensation agreement by the House of Representatives of the American Congress happened on 15 December 1981. ${ }^{31}$ In the course of discussion of bill H.R.5125 (compensation agreement) various congressmen spoke, but only three of them opposed acceptance of the legislation. The arguments given in support of the bill were as follows:

- The proposed compensation agreement meant for American claimants that the government of Czechoslovakia would pay 90.5 million USD, while the value of the gold is 108 million USD. This agreement is better than that from 1974, according to which Czechoslovakia would have paid only about 20 million USD;

- Acceptance of the compensation agreement would not bind the USA to grant most favoured nation status as it would have done in 1974;

- The proposed compensation agreement was a more appropriate solution than the original proposal to sell the Czechoslovak gold and satisfy the American claimants from interest payments. The sum of 81.5 million USD was the sort of amount that would be gained in 10 years from interest on the money gained by selling the gold;

- The advantage of the proposed compensation agreement was that payment of "cash" by Czechoslovakia would enable the claimants to "use" their money sooner;

- The proposal to sell the Czechoslovak gold (Wolff's bill) had enabled such a solution in favour of the USA because it convinced the government of Czechoslovakia that Congress really planned to sell the gold.

The arguments against acceptance of bill no. H.R.5125 were as follows:

- It was clear that not all the people who had lost property during the last 37 years would be satisfied;

- It was argued that the monetary gold belonged to the people and not to the communist government or that the Czechoslovak government did not represent the Czechoslovak people. ${ }^{32}$

30 AMZV ČR, f. MPO, Rokovania o .., vol. II, part A, ibid, p. 8-9.

31 National Czech and Slovak Museum and Library (NCSML), Cedar Rapids, f. CNCA, box No. 6, H.R.5125.

32 NCSML, Cedar Rapids, f. CNCA, box No. 6, H.R.5125. 
The president signed the act on 20 December 1981 on the basis of its approval by Congress. On the next day, the American Ambassador in Prague Jack F. Matlock informed the Czechoslovak Minister of Foreign Affairs Bohuslav Chňoupek about it.

The USA returned the Czechoslovak monetary gold on the basis of the above mentioned agreement in February 1982. ${ }^{33}$ So ended, probably the last open bilateral Czechoslovak - American question that had its "origin" in the years of the Second World War, and successfully for Czechoslovakia.

DER AMERIKANISCHE KONGRESS UND DAS TSCHECHOSLOWAKISCHE WÄHRUNGSGOLD 1980-1981

\section{SLAVOMÍR M I C H Á L E K}

Die Geschichte des tschechoslowakischen Währungsgoldes begann gegen Ende der 30en Jahre des zwanzigsten Jahrhunderts zur Zeit der Gebietsreduzierung und des Auseinanderbrechens der Tschechoslowakischen Republik. Damals war es gewaltig und rechtslos von dem nazistischen Deutschland geraubt. Zum Ende des zweiten Weltkrieges wurde das Gold von der amerikanischen Besatzungsarmee zusammen mit Gold anderer Länder in den deutschen Salzbergwerken in Merkers entdeckt. Erst im Jahre 1982 wurde ein angemessener Teil davon wieder nach Prag, bzw. in die Staatsbank der Tschechoslowakei zurückgeschickt.

Kurz nach dem zweiten Weltkrieg wurde von den USA, Großbritannien und Frankreich die Drei-Parteien-Kommission zur Restitution des Währungsgoldes errichtet. Diese Kommission entstand aufgrund des Beschlusses der Pariser Reparationskonferenz und ihre Aufgabe war es, das gefundene Gold proportional gerecht aufzuteilen und an alle betroffenen Länder, einschließlich der Tschechoslowakei, zurückzugeben. In den folgenden Jahrzehnten des kalten Krieges erschien das Gold regelmäßig als Gegenstand des Konfliktes, der Streitigkeiten und Verhandlungen vor allem in der Regie von Washington und Prag. Die getroffenen Vereinbarungen wurden durch eine oder die andere Seite gebrochen, oft hat man wieder vom Punkt Null angefangen. Die vorgelegte Studie be-

33 The actual transport of the gold from the USA and Great Britain through Switzerland was done in conditions of strict secrecy and extensive Czechoslovak security measures under the cover name "Akcia Návrat - Action Return". For more details see MICHÁLEK, Slavomír. Finále osudu československého zlata - akcia „Návrat 82“. (The finalé of the fate of the Czechoslovak gold - Action "Return 82"). In Dvě století nacionalismu: pocta prof. Janu Rychlikovi. Praha: Masarykův ústav, Archiv AV ČR; Univerzita Karlova v Praze, Filozofická fakulta, 2014, p. 248-271. ISBN 9788087782354. 
fasst sich mit dem Zeitraum 1980-1981, in dem sich der US-Kongress in die Frage der Zurückgabe des tschechoslowakischen Goldes bedeutungsvoll eingeschrieben hat.

PhDr. Slavomír Michálek, DrSc.

Historický ústav SAV

P. O. BOX 198, 81499 Bratislava, Klemensova 19

e-mail: histmich@savba.sk 